\title{
Seasonal changes in the abundance and diversity of birds in threatened juniper forest in the southern Asir mountains, Saudi Arabia
}

\author{
STEPHEN F. NEWTON and ANNE V. NEWTON
}

\section{Summary}

Juniper forest once covered much of the upper slopes $(2,000-3,000 \mathrm{~m})$ of the Rift Valley escarpment in the Asir mountains of south-west Saudi Arabia. One of the best preserved tracts is at Raydah near Abha, where a complete altitudinal floristic zonation persists. Although only about 125 bird species have been recorded in the area, the community is of considerable conservation interest due to high densities of endemic species and resident or breeding Afrotropical forest species, together with a wide range of diurnal raptors, owls and nightjars. The forest does not appear to support many PalearcticAfrican migrants during periods of passage, although several Palearctic species overwinter in considerable numbers. Scrub and mixed deciduous and riparian forest scattered throughout the junipers hold highest bird diversities but the juniper stands are vitally important to the well-being of Yemen Thrush Turdus menachensis, Yemen Warbler Parisoma buryi and Yemen Linnet Carduelis yemenensis populations. The disappearance of juniper forest from neighbouring Yemen necessitates that highest priority conservation action should be given to the remaining intact forests such as Raydah, in an attempt to preserve their unique biodiversity.

\section{Introduction}

Sandy and gravel deserts dominate the Arabian peninsula, though it is mountainous in the north-east (Oman and the United Arab Emirates) and south-west (Saudi Arabia and Yemen). Altitude ameliorates the effect of the prevailing arid climate, decreasing temperatures and increasing the likelihood of precipitation or condensation of moisture, and thus mountains and wadis can support a more diverse range of habitats which may climax in woodland or forest (McKinnon 1990).

Formerly, juniper forest covered a wide area of high mountains, from the Hajar in north Oman to the Yemen Highlands in the south (Abo-Hassan 1983, König 1986). However, the extent of these forests has been reduced considerably (Al-Hubaishi and Müller-Hohenstein 1984), due to human consumption for building and fuel wood and to overgrazing, which prevents regeneration. More insidiously, however, in many areas mature trees are currently known to suffer from die-back. This may have resulted from climate change (reduced 
precipitation or drought) exacerbated by a range of other biological stresses (Hajar 1991, Hajar et al. 1991, Gardner and Fisher 1994).

The avifaunal interest of the Asir mountains has long been recognized (Bates 1937), though relatively few studies have been made on the birds, because of problems of access and the difficult field conditions. Most effort has been devoted to compiling regional or local annotated species lists (King 1978, Jennings 1981, Stagg 1985), although more recently our knowledge of the south-west Arabian montane specialties has been improved considerably (Brooks et al. 1987, Jennings et al. 1988, Rands et al. 1987). Such information justifiably led to the designation of the overall region as an endemic bird area (ICBP 1992).

Given this importance, the National Commission for Wildlife Conservation and Development (NCWCD) initiated a long-term study of the avifauna of Raydah Reserve, one of the prime areas of intact juniper forest in south-west Saudi Arabia. The aims of the study described in this paper were to prepare a detailed inventory of the bird species occurring in the Reserve, particularly in forested and woodland habitats, and to elucidate their status, distribution and seasonality. This work complements concurrent detailed studies of other major biotopes and their avifaunal communities in south-west Saudi Arabia: Tihamah coastal plain (Rahmani et al. 1994), mountain wadis (Newton et al. 1994) and inland plateau desert (Newton and Newton in press).

\section{Study area}

Raydah Reserve is one of 10 sites currently given formal protection by NCWCD as part of their system plan for protected areas for wildlife conservation and sustainable rural development (Child and Grainger 1990). It is located $10 \mathrm{~km}$ west of the city of Abha in south-west Saudi Arabia (coordinates: $18^{\circ} 12^{\prime} \mathrm{N}$ $4^{\circ} 24^{\prime} \mathrm{E}$ ). The Raydah drainage system is enclosed by mountain ridges on the north and south flanks, with the eastern boundary running along the top of the escarpment at 2,850-2,700 m, falling to the Wadis Jaw and Maraba at about $1,300 \mathrm{~m}$. The measured area is approximately $9 \mathrm{~km}^{2}$, but given a fall of $1,000 \mathrm{~m}$ in $3 \mathrm{~km}$, we estimate the true ground area nearer $12 \mathrm{~km}^{2}$ (Figure 1 ). The village of Raydah lies at 1,600 m, just outside the Reserve.

The Asir region is known to receive relatively high rainfall in an Arabian context. No meteorological data are available for the Raydah escarpment area, although Khamis Mushayt, situated in the relatively arid upland plateau $(2,057 \mathrm{~m}) 40 \mathrm{~km}$ to the east, has a mean annual rainfall of $210 \mathrm{~mm}$ (Siraj 1984). Rainfall at Raydah could exceed this value about three-fold. In Khamis Mushayt highest rainfall occurs in spring (March to May) and summer (July and August) and our experience at Raydah concurs with this. However, it can rain substantially in any month at Raydah and for many days of the year the top of the escarpment is covered in cloud. A frequently observed pattern was for cloud to build up around midday, often leading to 1-3 hours of rain in mid-afternoon, followed by relatively clear evenings and mornings.

The vegetation shows distinct altitudinal zonation, although there are variations within zones, with much more forest on west- and north-facing slopes in the south-east and more open grassland and scrub on south-facing 


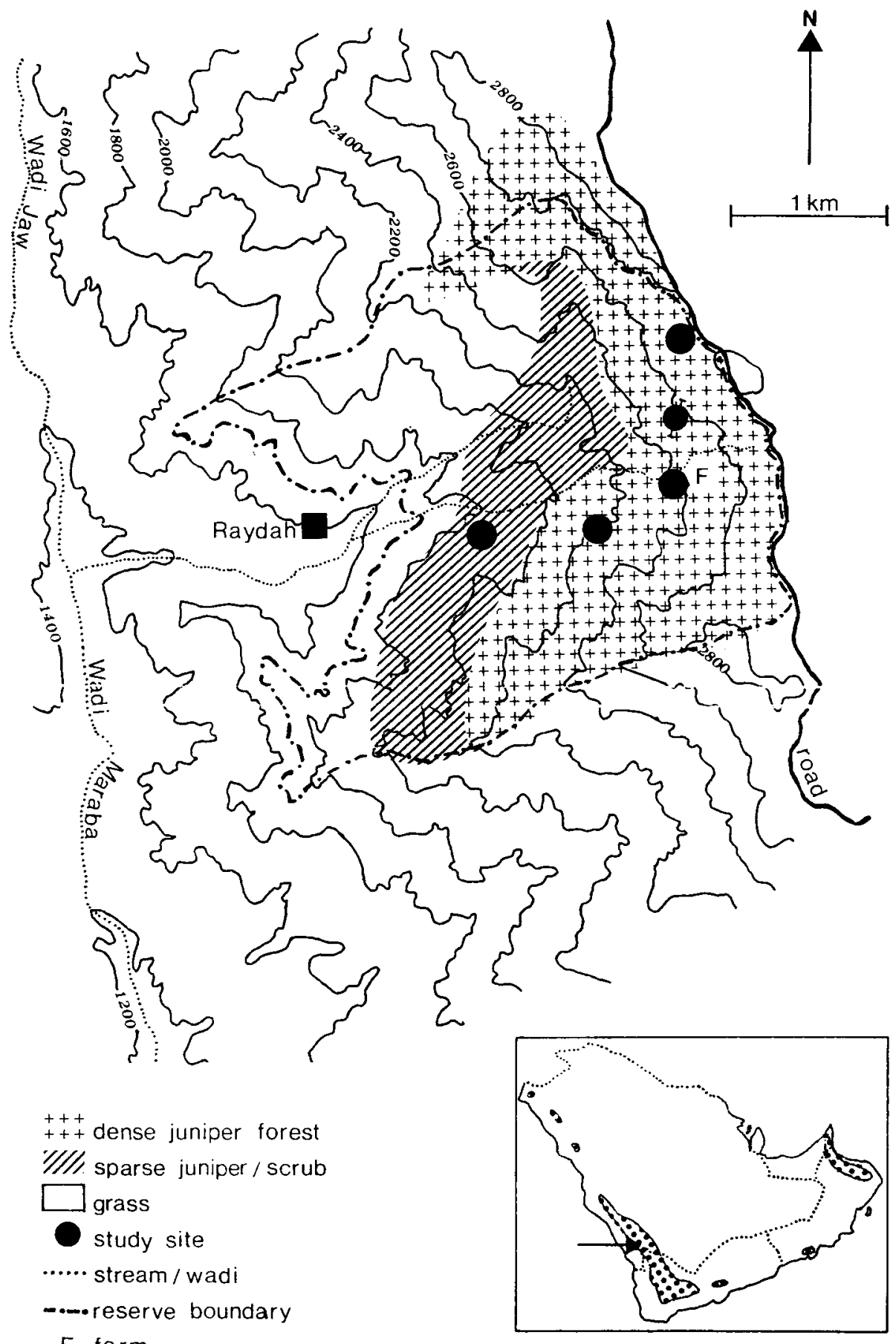

Figure 1. Location of study sites and approximate areas of forest types in Raydah Reserve, south-west Saudi Arabia. Principal mountain ranges (over 1,500 m high) in Arabia are shown by stippling (inset). 
Table 1. Dominant plant species recorded in each altitudinal zone in the forested, south-eastern half of Raydah Reserve.

\begin{tabular}{|c|c|}
\hline Altitude/major physical features & General habitat and dominant plant species \\
\hline $2,800-2,600 \mathrm{~m}$ & $\begin{array}{l}\text { Dense forest of Juniperus excelsa trees draped with } \\
\text { Usnea articulata lichen }\end{array}$ \\
\hline $2,600-2,300 \mathrm{~m}$ & Dense juniper without lichen \\
\hline $2,300-1,900 \mathrm{~m}$ & Mixed juniper and Olea africana forest \\
\hline $1,900-1,700 \mathrm{~m}$ & $\begin{array}{l}\text { Sparse die-back juniper, open scrubland with } \\
\text { Buddleja polystachia and Aloe sabaea }\end{array}$ \\
\hline Drainage lines & $\begin{array}{l}\text { Nuxia congesta, Ficus vasta, F. salcifolia, F. sycam- } \\
\text { orus, understorey shrub layer of Epilobium hirsu- } \\
\text { tum and Hypericum hircinum }\end{array}$ \\
\hline Rocky knolls & Opuntia ficus-indica, aloes \\
\hline Open scrubby areas, generally above $2,400 \mathrm{~m}$ & $\begin{array}{l}\text { Euryops arabicus, Nepeta deflersiana, Lavandula } \\
\text { dentata, Rosa abyssinica }\end{array}$ \\
\hline $\begin{array}{l}\text { Open scrubby areas, generally at } 2,000- \\
2,400 \mathrm{~m}\end{array}$ & Rumex nervosa, Dodonaea viscosa, Otostegia fruticosa \\
\hline $\begin{array}{l}\text { Throughout Reserve, although more frequent } \\
\text { below } 2,400 \mathrm{~m}\end{array}$ & $\begin{array}{l}\text { Trees and large shrubs Acacia origena, Pistacia fal- } \\
\text { cata, Teclea nobilis, Dombeya torrida, Tarchonanthus } \\
\text { comphoratus }\end{array}$ \\
\hline
\end{tabular}

slopes in the north-west. Wadi Raydah runs through the centre of the Reserve and, above 2,000 $\mathrm{m}$, is fed by several near permanent mountain streams. The lower section of the wadi bed is boulder-filled and surface flowing water is of rare occurrence. In the south and east, most ground above $2,000 \mathrm{~m}$ is forested, whereas in the north, forest is confined to above $2,400 \mathrm{~m}$. A bulldozed dirt road, passable with four-wheel-drive vehicles, connects Raydah village with the tarmac road at the top of the escarpment and an intermittently occupied, terraced farm lies at the centre of the forest area, close to the principal permanent stream. A full description of montane forest communities and zonation of this area is given in König (1986), but the dominant plant species in each zone of the forested south-eastern half of the Reserve are given in Table 1 .

\section{Methods}

Gathering thorough data on all members of a forest bird community is difficult, especially so in a mountainous area in the tropics (Karr 1981). There is no single census technique that covers all strata of the forest, in both breeding and non-breeding seasons. The steepness of the terrain and the thickness of the understorey with very limited visibility ruled out the option of line transects and would make any territory mapping procedure very difficult (Dawson 1981, Bibby et al. 1992). We therefore chose two main methods to estimate the distribution and abundance of birds: standardized mist-netting and point counts. Five study sites were monitored and recording methods and habitat types are given in Table 2.

\section{Constant effort mist-netting}

Mist-nets (mesh size $32 \mathrm{~mm}$ when stretched) were used to sample the birds across a range of habitats, primarily at the farm and top sites. Nets were 
Table 2. Study sites at Raydah Reserve, with approximate altitudes, survey methods and periods of observation.

\begin{tabular}{|c|c|c|c|c|}
\hline Site & Altitude (m) & Major habitats & Recording method & $\begin{array}{l}\text { Overall period } \\
\text { of observations }\end{array}$ \\
\hline Top a & 2,760 & Ridge, sparse juniper scrub & $\begin{array}{l}\text { Constant effort } \\
\text { mist-netting }\end{array}$ & Jan 94-July 95 \\
\hline Top b & 2,710 & $\begin{array}{l}\text { Open juniper forest with } \\
\text { clearings }\end{array}$ & $\begin{array}{l}\text { Constant effort } \\
\text { mist-netting }\end{array}$ & May 93-July 95 \\
\hline Top c & 2,710 & Closed canopy juniper forest & $\begin{array}{l}\text { Constant effort } \\
\text { mist-netting }\end{array}$ & May 93-July 95 \\
\hline Upper & $2,650-2,450$ & Juniper forest & $4 \times$ point counts & Sep 92-May 93 \\
\hline Farm & 2,400 & $\begin{array}{l}\text { Juniper forest; scrub and } \\
\text { overgrown farm terraces; }\end{array}$ & $\begin{array}{l}\text { Constant effort } \\
\text { mist-netting }\end{array}$ & Mar 92-July 95 \\
\hline & & mixed riparian forest & $4 \times$ point counts. & June 92-Jan 94 \\
\hline Middle & 2,200 & $\begin{array}{l}\text { Mixed forest with die-back } \\
\text { junipers }\end{array}$ & $3 \times$ point counts & Apr 92-Mar 94 \\
\hline Lower & 1,850 & $\begin{array}{l}\text { Open scrubland of Aloe and } \\
\text { Buddleja, sparse junipers } \\
\text { (dead and severe die-back) }\end{array}$ & $2 \times$ point counts & May 92-Mar 94 \\
\hline
\end{tabular}

Altitudes taken from K.S.A. Ministry of Petroleum and Mineral Resources 1 : 50,000 sheet 4218-32.

operated at fixed locations for the daylight hours in a 24 -hour period, generally from dawn until dusk. A minimum of nine nets, totalling $108 \mathrm{~m}$, was always operated at the farm and eight nets, totalling $93 \mathrm{~m}$, at the top site. Other additional nets were operated occasionally when opportunities arose (extra manpower, etc.). All catches were standardized as number of birds caught per to $\mathrm{m}$ net per hour for a particular habitat type at a given study site.

\section{Point counts}

Counts of birds were made at fixed points (a minimum of $100 \mathrm{~m}$ apart) and were conducted principally at the middle and lower sites and to a lesser extent at the farm and upper site. Registrations were based on sightings and/or numbers of birds singing, within a $50 \mathrm{~m}$ radius of the observer in a half-hour period. Birds flying over the point count area were excluded unless they alighted in the area or showed signs of foraging (e.g. a hovering Kestrel Falco tinnunculus). Most counts were undertaken in the morning between o7h3o and 11 hoo and were preceded by a pause of 2-4 minutes to allow birds to settle.

Owing to the open habitat and good visibility at the lower site and given so few birds were present, the point count radius was increased to $100 \mathrm{~m}$. The difference in area was standardized when bird densities were calculated, as numbers of birds per hectare.

\section{General observations}

For miscellaneous observations gathered outside the standardized methodologies, the following information was recorded: numbers, habitat, altitude and evidence of breeding or other activity used to elucidate status. 
Table 3. Definitions and abbreviations of status, habitat and abundance codes for birds recorded in Raydah Reserve.

\begin{tabular}{|c|c|c|}
\hline Variable & Abbreviation & Definition \\
\hline \multirow[t]{6}{*}{ Status } & $\mathrm{RB}$ & Present throughout the year and breeding \\
\hline & MB & Migrant breeder, present in spring and summer only \\
\hline & LV & $\begin{array}{l}\text { Local visitor, usually a resident species, but only breeding } \\
\text { in habitats surrounding the Reserve }\end{array}$ \\
\hline & PM & Passage migrant \\
\hline & WV & Winter visitor \\
\hline & SU & $\begin{array}{l}\text { Status uncertain, species either vagrant or recorded very } \\
\text { erratically }\end{array}$ \\
\hline \multirow[t]{5}{*}{ Habitat } & $F ; F_{1} ; F_{M}$ & Forest/woodland; J, juniper; $M$, mixed and/or riparian \\
\hline & $\mathbf{R}$ & Rocky ground, cliffs \\
\hline & $\mathrm{S} ; \mathrm{S}_{\mathrm{L}} ; \mathrm{S}_{\mathrm{H}}$ & $\begin{array}{l}\text { Scrub, including rocky grassland; L, low altitude; } \mathrm{H} \text {, high } \\
\text { altitude }\end{array}$ \\
\hline & $\mathrm{H} ; \mathrm{H}_{\mathrm{H}}$ & Human habitation/structures; at high altitude \\
\hline & W & Wadi \\
\hline \multirow[t]{4}{*}{ Abundance } & $\mathrm{a} ; \mathrm{A}$ & Abundant non-breeder; $>500$ pairs breeding in the Reserve \\
\hline & $\mathrm{c} ; \mathrm{C}$ & Common non-breeder; $51-500$ pairs breeding in the Reserve \\
\hline & $\mathrm{s} ; \mathrm{S}$ & Scarce non-breeder; $6-50$ pairs breeding in the Reserve \\
\hline & $\mathrm{r} ; \mathrm{R}$ & Rare non-breeder; $1-5$ pairs breeding in the Reserve \\
\hline Zoogeographical & PAL & Palaearctic \\
\hline \multirow[t]{4}{*}{ Realm } & $\mathrm{AT}$ & Afrotropical \\
\hline & $\mathrm{OR}$ & Oriental \\
\hline & ME & Restricted to the Middle East/North Africa \\
\hline & END & Endemic to Arabia \\
\hline Conservation & 1 & Globally threatened \\
\hline \multirow[t]{2}{*}{ Status } & 3 & Threatened or declining in the Middle East \\
\hline & 4 & $\begin{array}{l}\text { Species with small world range, mostly restricted to Middle } \\
\text { East }\end{array}$ \\
\hline
\end{tabular}

Conservation status codes as defined by Evans (1994).

Definitions of status, habitat and abundance codes are listed in Table 3. Estimates of the number of pairs breeding in the Reserve were derived from such observations in combination with densities of singing (territorial) birds made during point counts in the breeding season.

\section{Diversity and dominance indices}

Indices of diversity and dominance were calculated: Margalef's species richness index $\mathrm{D}_{\mathrm{Mg}}=(S-1) / \mathrm{ln} N$, where $S$ is the total number of species recorded in a point count or netting session (in a particular habitat type) and $N$ is the total number of individuals; the Berger-Parker index $d=N_{\max } / N$, where $N_{\max }$ is the number of individuals of the most abundant species and $N$ is the total number of individuals recorded (of all species) (Magurran 1988).

\section{Results}

The study area was visited for periods of 3-7 days, approximately 4-6 times per year between 1992 and 1995. Greatest field effort was allocated to the spring/ summer breeding season (March-July), with a total of 14 out of 20 sessions, 
and the remaining sessions were divided equally between autumn (SeptemberOctober) and winter (November-January) seasons. General records from two single-day visits in January 1993 and July 1994 are also included.

\section{Numbers of bird species recorded}

The total number of bird species recorded during the study (1992-1995) was 98 (Table 4). The number of species varied between months (19-51), the maximum counts usually being recorded in March and, especially, September (Figure 2). Numbers of species increased with altitude in the forest: top, 15-30 species; middle, 10-20 species and lower, 5-10 species per month. The farm site usually held 25-35 species, due to the greater variety of habitat types (Table 2).

\section{Community composition}

Approximately $37 \%$ of all bird species recorded were resident breeders (although some almost certainly undertake local altitudinal migrations, e.g. Palm Dove Streptopelia senegalensis, Little Rock Thrush Monticola rufocinerea); $16 \%$ were local visitors (some of which may breed in the forest in some years); $5 \%$ were migrant breeders; $7 \%$ were winter visitors and $32 \%$ were passage migrants. Thus, overall $58 \%$ of species bred in or very close to the Reserve and $39 \%$ were passage migrants or winter visitors. The terrestrial endemic and near endemic species included all those known to occur in Saudi Arabia with the exception of the Arabian Golden Sparrow Passer euchlorus, which throughout its range is only known from the Tihamah coastal plain. Most passage migrants were passerines and the majority were seldom recorded in the forest in any numbers, with the exception of species which also overwintered, notably Song Thrush Turdus philomelos, Blackcap Sylvia atricapilla, Chiffchaff Phylloscopus collybita and perhaps Redstart Phoenicurus phoenicurus. Thus, the juniper forest avifauna was dominated by resident species, either of Afrotropical origin or endemic to south-west Arabia, and a few species, numerically common, of overwintering Palearctic migrants. Exceptionally, in September 1993, 32\% of the species recorded were migrants (Figure 3 ). The proportion of migrants was generally lowest in the period between May and July, except for an unusually high proportion of migrants in May 1994.

\section{Patterns of forest-habitat utilization}

This section uses mist-net capture rates and indices of diversity and dominance derived from such data to investigate relatively fine-scale differences between forested subhabitats and scrub with good cover at middle and higher altitudes in the juniper zone. Figures 4,5 and 6 illustrate variations in bird activity between months, pooled between years, and subhabitats at the two netting sites.

At the farm site, capture rates were highest in the nets set over or close to the stream in mixed deciduous woodland in all months from March to September, with peaks in June and July (Figure 4). Scrubby habitats generally caught at intermediate rates, but had the highest rates overall in October and November; capture rates in juniper forest were considerably lower, though 


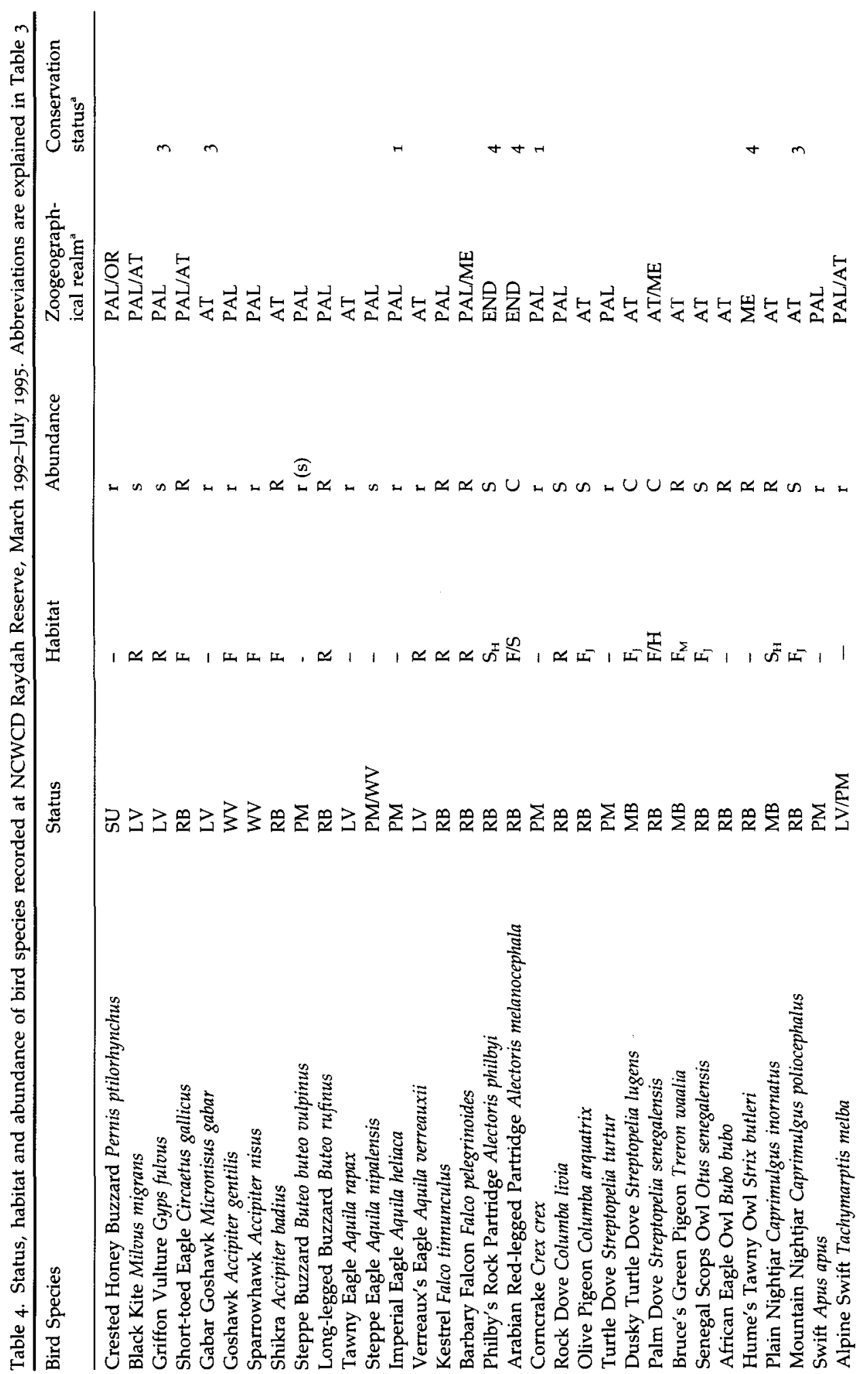




$$
\begin{aligned}
& 0 \\
& 0
\end{aligned}
$$

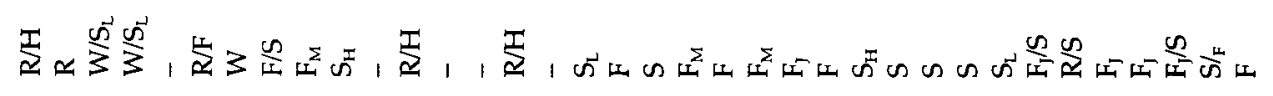

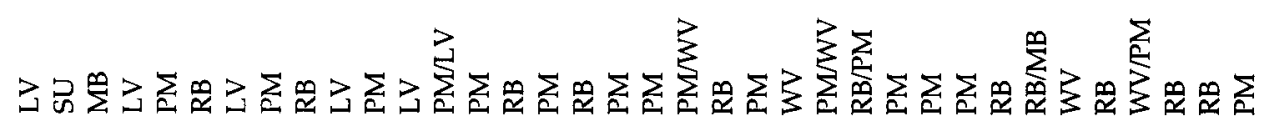

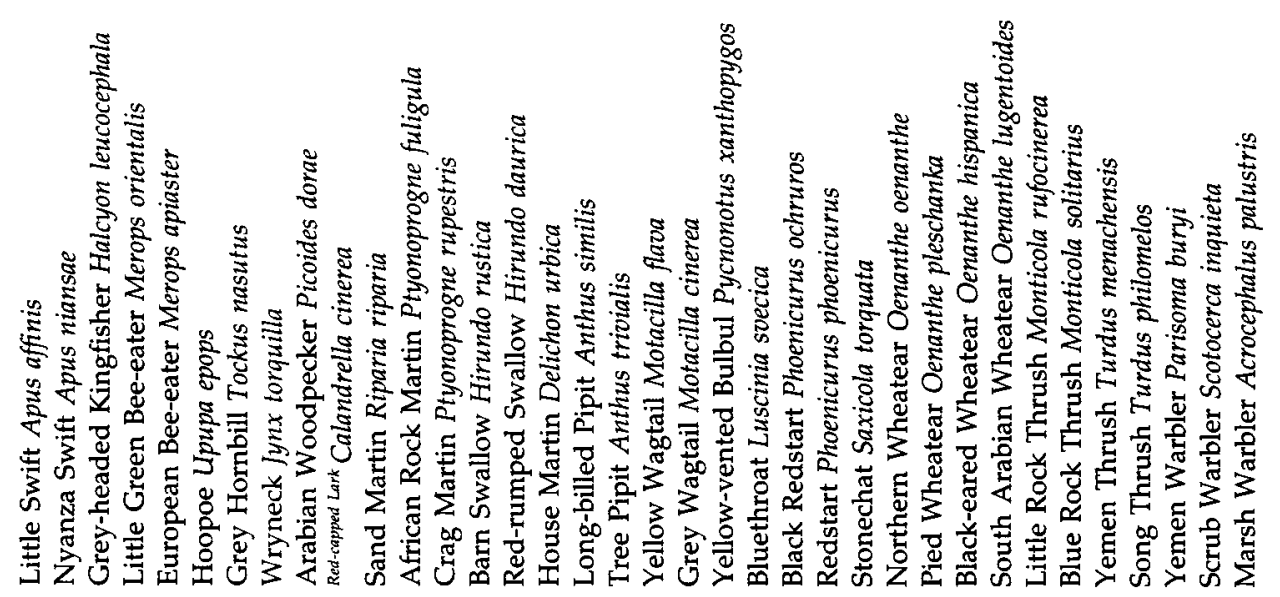




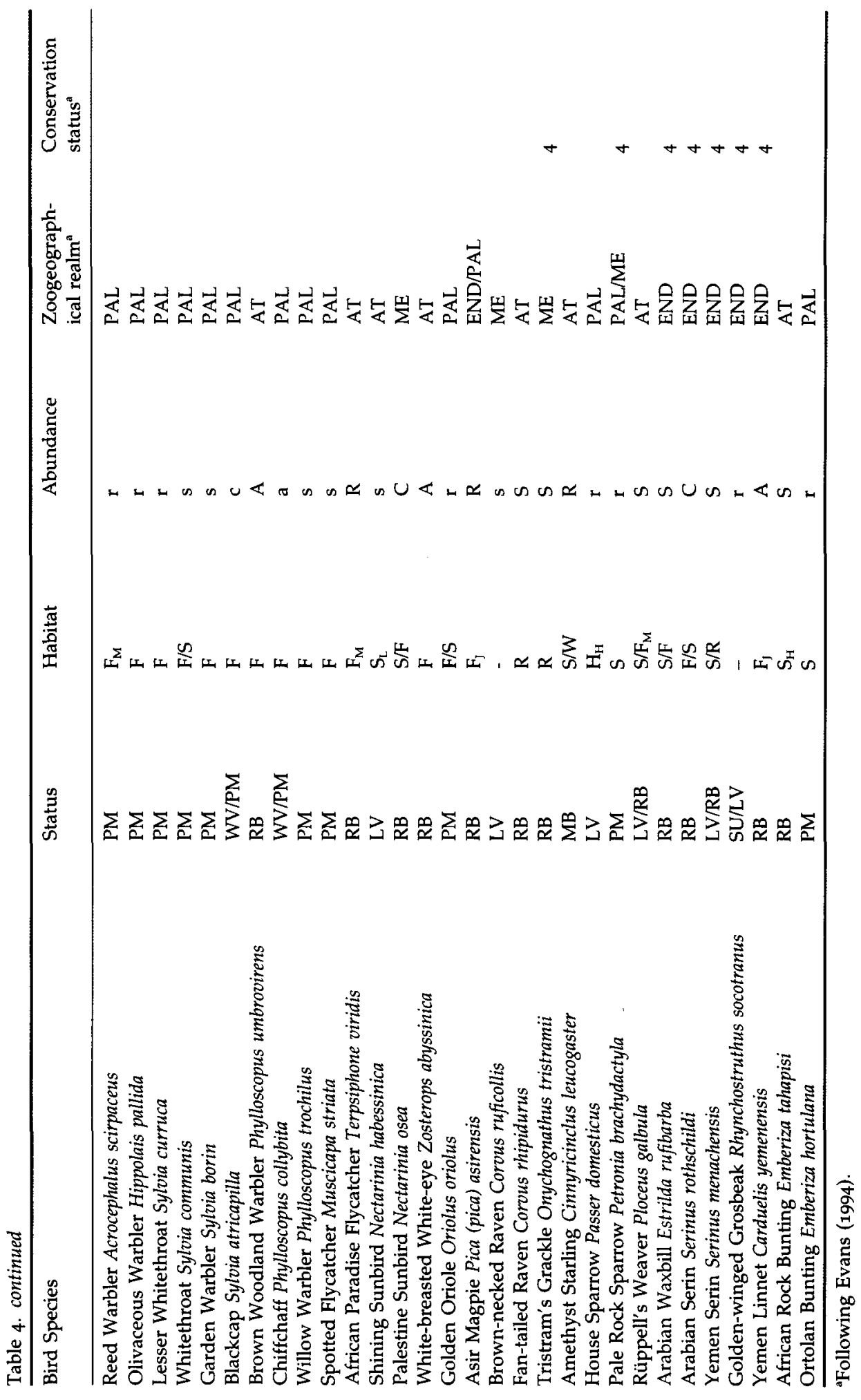




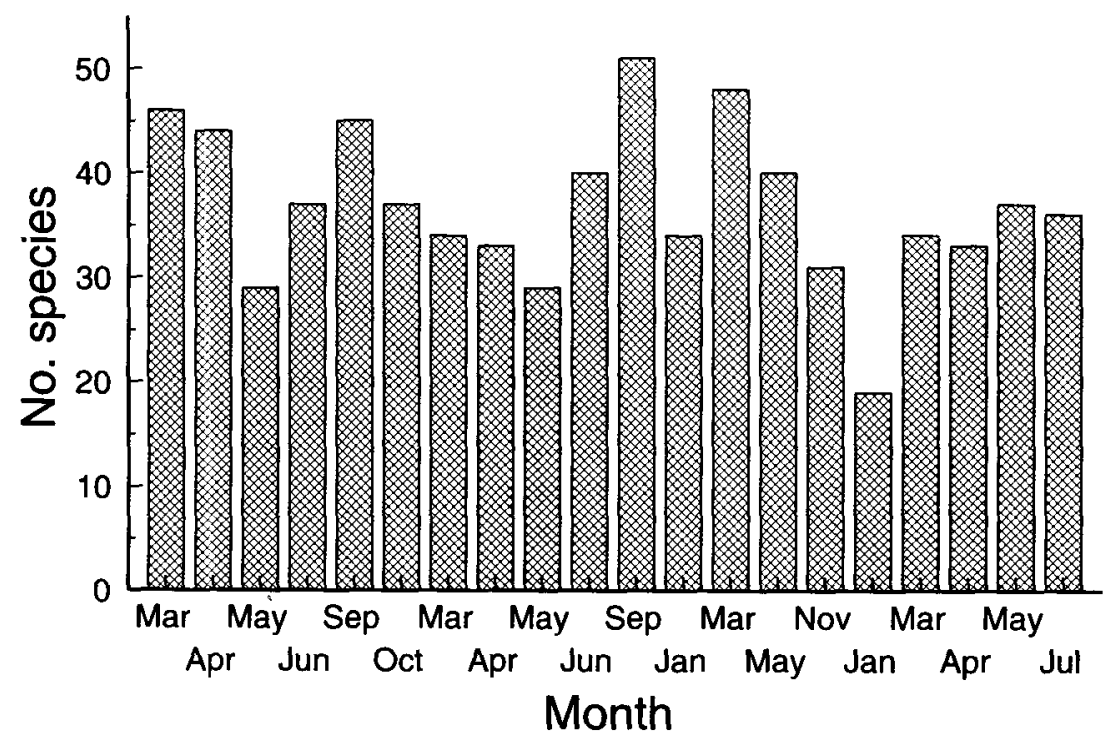

Figure 2. Numbers of birds species recorded in different months in Raydah Reserve, March 1992-July 1995.

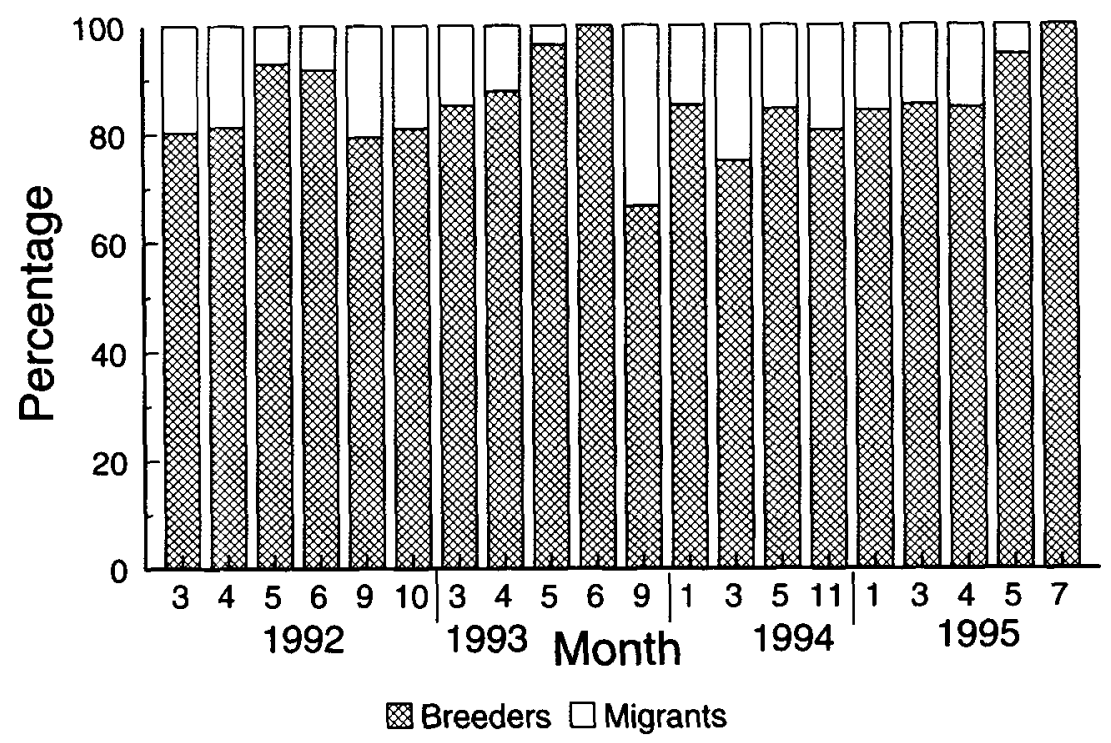

Figure 3. Percentage of breeding (residents and summer visitors) and migrant (winter and passage) species in Raydah Reserve, March 1992-July 1995.

similar to the two denser juniper habitats at the top, and showed no seasonal variation. At the top site, capture rates in most months were highest for nets set along the ridge, intermediate in more open juniper forest and lowest in dense understorey (enclosed) junipers. The highest capture rates occurred in the breeding season (April to July) and, in the ridge nets, in late November 


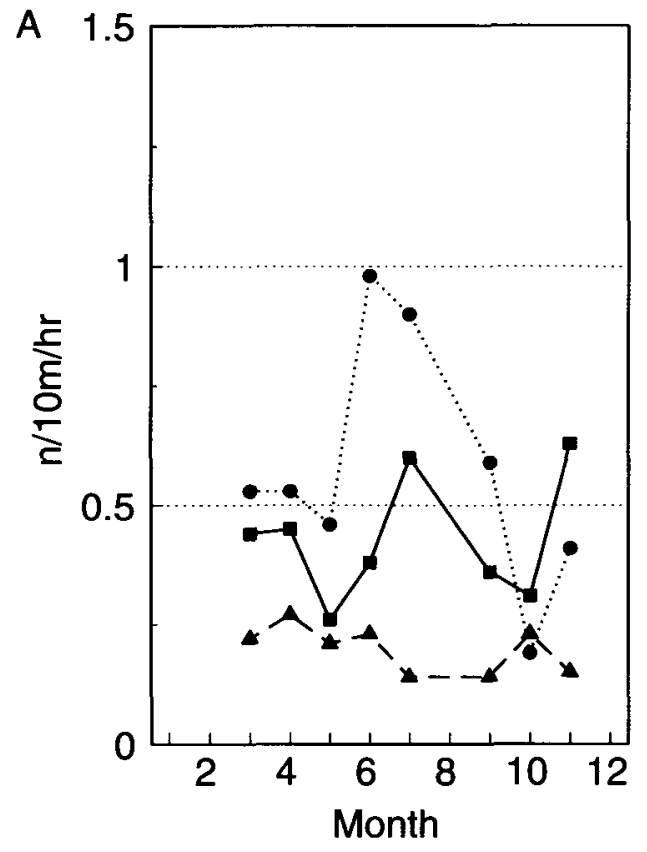

Scrub Juniper Stream

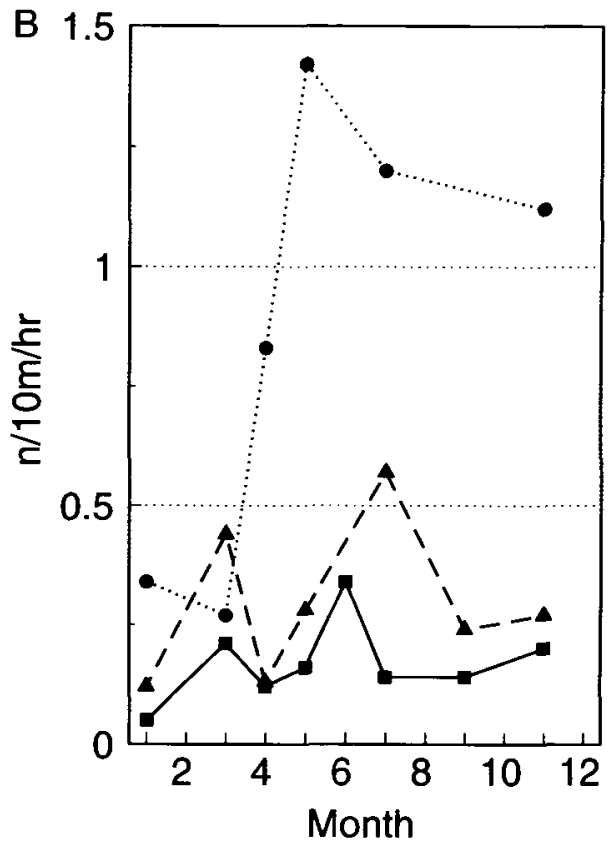

Enclosed Open Ridge

Figure 4. Numbers of birds caught per $10 \mathrm{~m}$ of mist net per hour by month at (A) the farm and (B) the top site, Raydah Reserve.

when there was active Song Thrush migration. However, apart from the ridge in May, July and November, levels at the farm $(2,400 \mathrm{~m})$ were slightly higher than at the top, no doubt attributable to the farm's greater diversity of habitats.

Species richness indices at the farm and top sites lay largely between 1.5 and 2.5 (Figure 5a). At the farm, higher diversities were recorded in scrub / terrace and stream habitats while monospecific juniper stands were generally lowest. However, there was little variability between habitats in March, May and June. Species richness indices were slightly more variable at the top site, despite all subhabitats being dominated by juniper (Figure $5 \mathrm{~b}$ ). The more open juniper and ridge nets recorded highest diversities in months when maximum numbers of passage migrants were present (March, April and September). Indices in the enclosed juniper nets were higher than the other subhabitats in the winter months (November and January, species seeking shelter) and in summer (June and July, subcanopy activity due to nesting).

Dominance indices for the farm lay predominantly in the range $0.3-0.4$. Only in May was apparent dominance registered (0.59), in the nets near the stream (Figure 6a), when Yemen Linnets Carduelis yemenensis in two years and White-breasted White-eyes Zosterops abyssinica in two years were the dominant species caught. In contrast to the farm, there was a wider scatter of species-dominance indices at the top nets, though the majority lay between 0.2 and 0.6 (Figure 6b). However, in seven "subhabitat months", indices were equal to or exceeded 0.5: April, May and July on the ridge and January, April, May and July in open juniper forest. In all cases, dominance in the spring and 


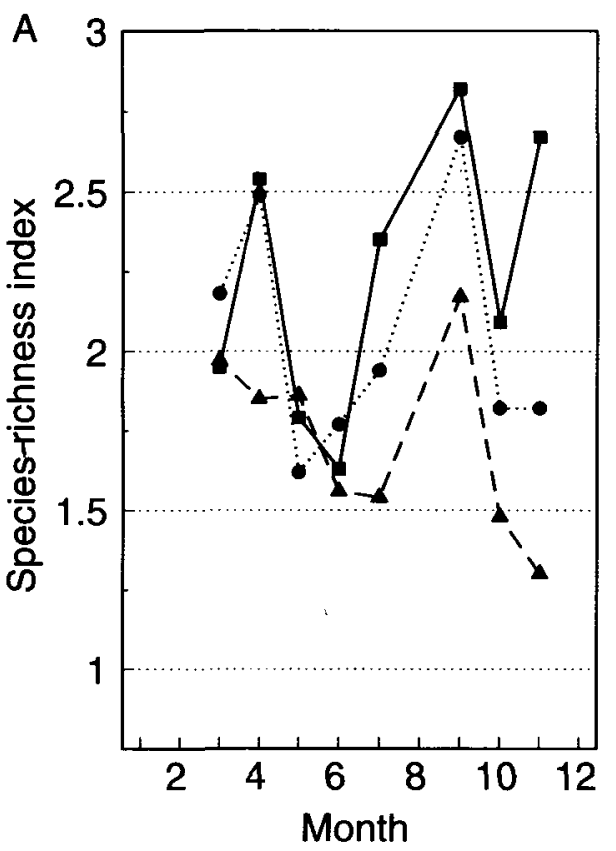

Scrub Juniper Stream

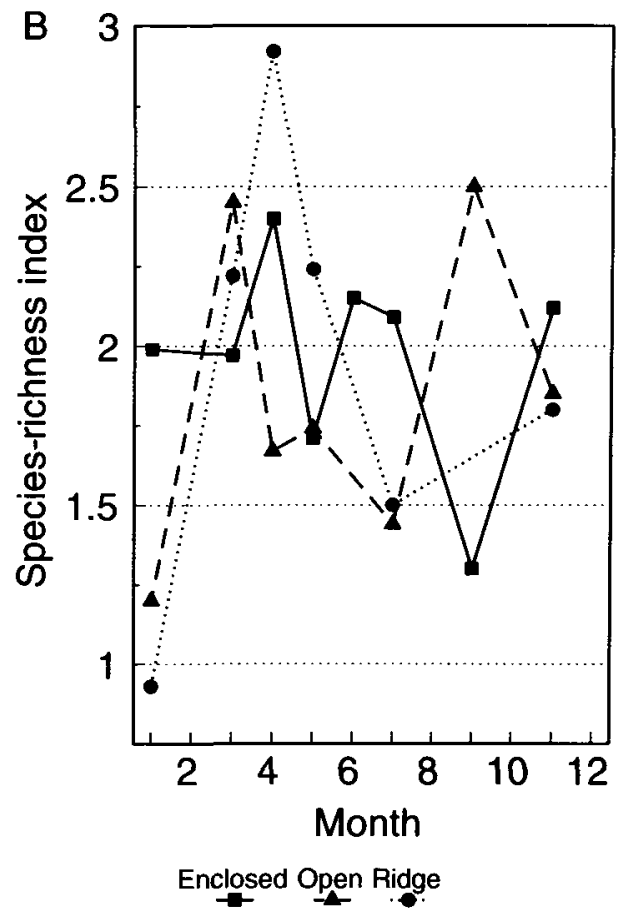

Figure 5. Margalef's species richness diversity indices, by month, based on mist net captures at (A) the farm and (B) the top site, Raydah Reserve.

summer months was due to the intense breeding activity by Yemen Linnets in more open junipers and to large numbers of Blackcaps caught in May 1994, whereas January dominance was attributable to Song Thrushes (1995) and Black Redstarts Phoenicurus ochruros (1994).

\section{Altitudinal variation in bird density, species diversity and dominance}

Total numbers of birds detected in point counts were expressed per hectare to give monthly densities, pooled across years, at different altitudes (Figure 7). Densities at the three higher study sites (predominantly forest) usually ranged between 15 and 30 birds per hectare from January to September, but fell in October. Densities at the lower site in open, dry, scrub were always the lowest recorded (generally $1-3$ birds/ha); however, unlike the other sites, density was highest in January ( 5 birds/ha).

Early in the year, slightly higher densities were recorded in the mixed forest of the mid site than in juniper dominated sites at higher altitudes. This finding, coupled with the higher January densities at the lower site, indicates downslope altitudinal shift by some components of the bird community.

Species richness indices, averaged from individual point counts at each study site, typically ranged from 1.5 to a maximum of 4.2 (Figure 8). Patterns were broadly similar in each study site, with high indices from March to June and in September, a dip in July and uniformly low scores in October (1992). Species 

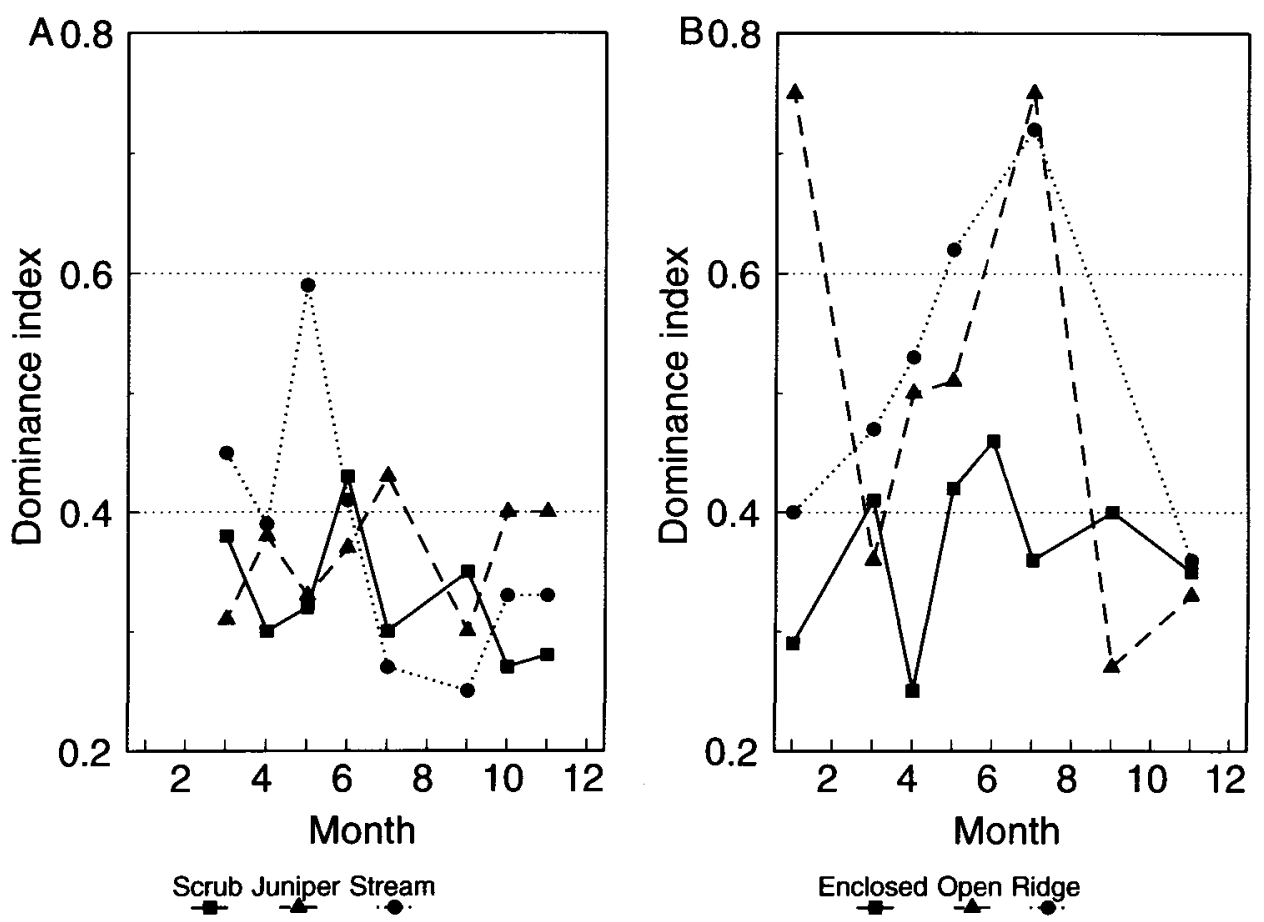

Figure 6. Berger-Parker dominance diversity indices, by month, based on mist net captures at (A) the farm and (B) the top site, Raydah Reserve.

richness was generally highest in the mixed woodland of the mid site, except in September, intermediate at the farm and lowest in the lower, open, scrub woodland. However, relatively high diversity was recorded at the lower site in January (1994), again supporting evidence for altitudinal migration within the forest avifauna. At most study sites, between-plot habitat variability was low and species richness indices consistent, except at the farm where three plots were in juniper stands and one in abandoned terraces and mixed riparian woodland; in the latter, consistently higher indices were registered between April and September, due to the preference of some scarce species to nest in this habitat (Bruce's Green Pigeon Treron waalia, African Paradise Flycatcher Terpsiphone viridis, Rüppell's Weaver Ploceus galbula). For the farm, these diversity indices were somewhat higher than those based on mist-net observations (Figures 5a,8). Clearly mist-netting, restricted to the lower $3 \mathrm{~m}$ of the forest vertical structure, does not sample the full range of species present at a site.

Virtually all dominance indices computed from point count observations lay in the range $0.2-0.4$, concurring with mist-net indices; it was clear that no single species dominated the avifauna of the four study sites, as only indices above 0.5 would indicate a strong degree of dominance. There was no clear pattern to these indices between sites or months. 


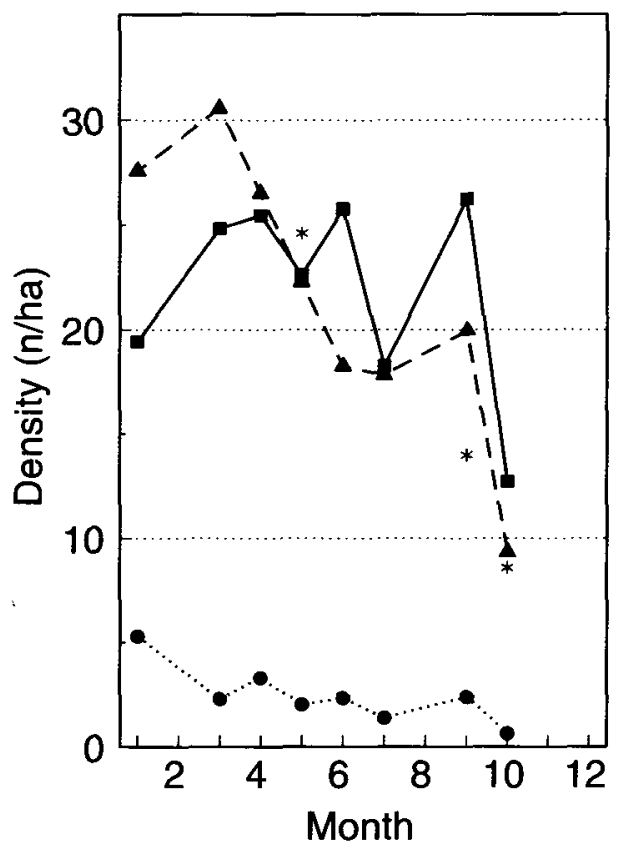

\section{Farm Mid Lower Upper}

Figure 7. Density of birds per hectare by month, estimated from point counts at four study sites in Raydah Reserve.

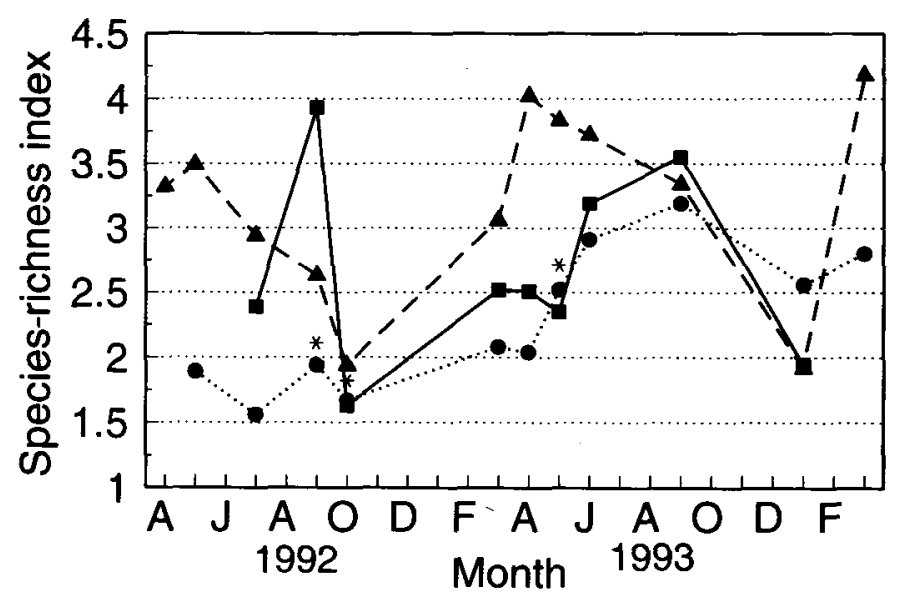

Farm Mjd Lower Upper

Figure 8. Margalef's species richness diversity indices of birds recorded in point counts at four study sites in Raydah Reserve, between April 1992 and March 1994. 


\section{Discussion}

\section{Methodology}

The necessity for using a combination of census techniques in this study area was demonstrated clearly. Resident species were generally conspicuous or vocally active and thus highly detectable, whereas some species of passage migrants and winter visitors were rarely seen or heard and were most often recorded when caught in nets. However, in certain habitats, the opposite was true and some bird species were seen or heard but were not caught in mist-nets. Given that mature forest of Juniper excelsa in the Asir generally has a canopy height of 5-8 $\mathrm{m}$, then our 2.5-3 m high mist-nets usually sampled only about half of the vertical structure, which is, nonetheless, more than in other dry tropical forest. The use of a combined methodology ensured that as wide a spectrum of species as possible was recorded and our sampling methods could be repeated in the future.

\section{Habitat associations}

Each habitat in our study area had subtle, but characteristic, differences in avian community compositions amongst the resident or breeding species. Most measures of avian diversity and density, including standardized capture rates and species richness indices, were highest in non-juniper dominated habitats. However, juniper forest is the most extensive habitat, covering about $50 \%$ of the entire Reserve and $75 \%$ of forested parts of the Reserve. The above indices draw attention away from the fact that the relatively low diversity juniper avifauna largely comprises endemic species, especially Yemen Thrush Turdus menachensis, Yemen Warbler Parisoma buryi and Yemen Linnet often present at high densities. The former and latter are certainly very dependent on juniper berries as a food source and most nests are built in juniper trees. Additionally, low density species of high conservation interest were mostly seen or heard in juniper habitats, though were seldom detected by mist-netting or point counts, e.g. Mountain Nightjar Caprimulgus poliocephalus, Olive Pigeon Columba arquatrix and Asir Magpie Pica (pica) asirensis. Both endemic partridge species were common in juniper-dominated habitats, especially where rocky knolls and clearings occurred. Given much of our work involved mist-netting, it is not surprising that scrub habitats often recorded higher diversity than forest, where we were unable to sample at canopy heights. Some mist-netting trials undertaken at the mid study area in mixed deciduous forest with the canopy at $10-15 \mathrm{~m}$ yielded exceedingly low capture rates; concurrent point counts showed most bird activity to be in the middle storey and canopy.

\section{Community composition}

The montane juniper forest at Raydah and elsewhere in the Asir region is dominated by a relatively low number of resident species living at high densities. Equivalent trapping intensity in acacia woodland, gardens or scrub 
land on the Red Sea coast, Tihamah or the interior plateau conducted during the same time period yielded a far higher ratio of migrants to residents. At present, we are uncertain as to why so few Palearctic-Afrotropical migrants are detected in the juniper forests along the south-west Saudi Arabian escarpment during spring and autumn, as migrants are found very close to the escarpment on both sides, in non-juniper habitats, during both passage periods. Several of the more common winter visitors are superficially similar, in terms of morphology and ecology, to resident species (Song Thrush and Yemen Thrush, Black Redstart and Little Rock Thrush, Chiffchaff and Brown Woodland Warbler Phylloscopus umbrovirens) and apparently co-exist at considerable densities for much of the year (October-April). These topics certainly require further scrutiny in the light of recent information coming from the Andes and Amazon Basin of South America. In this area, Robinson et al. (1995) have shown that species richness of wintering neotropical migrants and residents are inversely correlated and that the former are more common in early successional habitats (including disturbed areas and second growth forest) rather than primary forest.

\section{Changes in the regional avifauna since previous work}

As in much of south-west Arabia, our understanding of the true status of some scarcer species is often thwarted by lack of coverage in all months or seasons. The ornithological monitoring reported here has clarified some of these remaining problems. The Short-toed Eagle Circaetus gallicus and Shikra Accipiter badius are now confirmed as resident breeding species in the Asir, although the former is also a local passage migrant to the Tihamah foothills and inland plateau. Our observations of a Goshawk Accipiter gentilis in the juniper forest in late November indicates that this species is probably a rare winter visitor. Following the discovery of the Olive Pigeon in Arabia in 1975 (Jennings 1986), its status has been in question; although we have not proven breeding, birds are present in the juniper forest throughout the year and the likelihood of annual migrations to and from Africa seems remote. Their colonization may have been reasonably recent but on the other hand they could have eluded detection by early ornithologists and be a relatively longstanding resident species.

The discovery of a significant population of the Mountain Nightjar in Arabia has already been described in detail (Symens et al. 1994); it is very likely that these Arabian birds are a distinct subspecies and it appears that they occur in highest densities in intact juniper forest. Additionally, the Plain Nightjar Caprimulgus inornatus has now been established as a common breeding migrant in much of the more barren mountains in south-west Arabia. It certainly ranges from the Taif area (Newton 1994) to south Yemen (Martins et al. 1993) and in several places is associated with junipers.

The only reasonably certain loss to the avifauna of the Raydah area is the Bearded Vulture Gypaetus barbatus. The demise of this species in Saudi Arabia since the early to mid 1980s (Jennings 1981, Stagg 1985) has been dramatic and none were seen from 1992 to 1995. Also, numbers of Griffon Vultures Gyps fulvus breeding in the Abha area appear to have declined considerably (Jennings et al. 1988). The Golden-winged Grosbeak Rhynchostruthus socotranus is another 
species that may be declining locally. Jennings (1981), Stagg (1985) and Jennings et al. (1988) all indicate that this species is a typical bird of the Asir junipers but during the course of 20 visits to Raydah over four years, we have only seen the species very briefly on two occasions, in April and September 1992. Based on recent descriptions of nesting habitat in Dhofar and the adjacent Mahra in eastern Yemen (Brown 1993, Martins et al. 1993), it seems likely that juniper forest may not be the typical or preferred habitat of this species in Arabia (cf. Jennings 1995). Similarly, the Arabian Woodpecker Picoides dorae appears to prefer acacia rather than juniper (Winkler et al. 1996).

A further 26 species have been recorded in the Reserve prior to 1992 or around the boundaries (Table 5) and all could potentially occur in the junipers from time to time. Apart from passage migrants, most are wadi bottom species or birds of more open highland habitat, including terraced farmland and juniper scrub.

\section{Conservation importance and major threats}

The recent review of Middle Eastern sites and species, undertaken as part of the Important Bird Areas project (Evans 1994), included four lists of species of high conservation interest (those occurring at Raydah are indicated in Table 4). It is our opinion that the endemics (including near-endemics and endemic subspecies) should all receive equal treatment; data presented here and our observations at other Juniperus/Olea forests and Acacia woodlands in the Asir suggest that the Yemen Thrush should not be alone in being listed as globally endangered. Species such as the Arabian Woodpecker, although widely distributed, generally occurs at low densities and if anything the Yemen Warbler is much more limited geographically in both Yemen and Saudi Arabia (Jennings 1995) and, where it does occur, numbers are much lower. A case may be argued that all of the montane endemics should be considered globally endangered, or at least treated consistently, given their relatively small world range and the development pressure on the high mountain areas of Saudi Arabia (and perhaps Yemen), which harbour the major tracts of forest. Additionally we would recommend that the conservation status of most Afrotropical forest species occurring in south-west Arabia should be elevated above some of those which are common in much of Arabia (e.g. Yellow-vented Bulbul Pycnonotus xanthopygos, Arabian Babbler Turdoides squamiceps, Tristram's Grackle Onychognathus tristramii and Pale Rock Sparrow Petronia brachydactyla), in a wider range of habitat types which are not particularly under threat.

Montane Juniperus excelsa forests are also present on the southern side of the Red Sea in Eritrea; their escarpment setting, climate and floristic composition are very similar (Smith 1957, Jones 1991). However, Eritrea does not seem to have such a characteristic juniper avifauna, as Smith (1957) states "no species is wholly associated with this habitat". Species common to both areas include Little Rock Thrush, Brown Woodland Warbler and White-breasted White-eye. This view accords well with Jennings (1995), who also considers that no Arabian species is directly or indirectly dependent on junipers. However, since the distribution of junipers (present and former) and many endemics show high concordance in montane areas of south-west Arabia, an interesting question is 
Table 5. Species recorded in, or in close proximity to, Raydah Reserve prior to 1992, or contemporaneously by others not associated with the NCWCD programme. Abbreviations are explained in Table 3 .

\begin{tabular}{|c|c|c|c|c|}
\hline Species & $\begin{array}{l}\text { Status in } \\
\text { SW Arabia }\end{array}$ & Wadi $^{\mathrm{a}}$ & Reserve $^{b}$ & East $^{\mathrm{c}}$ \\
\hline $\begin{array}{l}\text { Pintail Anas acuta (feather } \\
\text { only; predated by raptor?) }\end{array}$ & $\mathrm{PM} / \mathrm{WV}$ & & $\times$ & \\
\hline Red-eyed Dove & ?RB & & $x$ & \\
\hline $\begin{array}{l}\text { Streptopelia semitorquata } \\
\text { Jacobin Cuckoo }\end{array}$ & SU & & $x$ & \\
\hline Clamator jacobinus & & & & \\
\hline $\begin{array}{l}\text { Didric Cuckoo } \\
\text { Chrysococcyx caprius }\end{array}$ & SU & & & $x$ \\
\hline $\begin{array}{l}\text { Klaas's Cuckoo } \\
\text { Chrysococcyx klaas }\end{array}$ & $\mathrm{BM}$ & $x$ & $x$ & \\
\hline $\begin{array}{l}\text { White-browed Coucal } \\
\text { Centropus superciliosus }\end{array}$ & RB & $x$ & & \\
\hline $\begin{array}{l}\text { Nubian Nightjar } \\
\text { Caprimulgus nubicus }\end{array}$ & $\mathrm{BM} / \mathrm{RB}$ & $x$ & & \\
\hline Pallid Swift Apus pallidus & PM & $x$ & & \\
\hline $\begin{array}{l}\text { White-throated Bee-eater } \\
\text { Merops alibcollis }\end{array}$ & $\mathrm{BM}$ & $x$ & & \\
\hline $\begin{array}{l}\text { Abyssinian Roller } \\
\text { Coracias abyssinicus }\end{array}$ & RB & $x$ & & \\
\hline Crested Lark Galerida cristata & RB & & & $x$ \\
\hline $\begin{array}{l}\text { Richard's Pipit } \\
\text { Anthus novaeseelandiae }\end{array}$ & SU & & $x$ & \\
\hline $\begin{array}{l}\text { Black Bush Robin } \\
\text { Cercotrichas podobe }\end{array}$ & RB & $x$ & & \\
\hline Blackstart Cercomela melanura & RB & $x$ & & \\
\hline $\begin{array}{l}\text { Red-breasted Wheatear } \\
\text { Oenanthe bottae }\end{array}$ & RB & & & $x$ \\
\hline $\begin{array}{l}\text { Graceful Warbler } \\
\text { Prinia gracilis }\end{array}$ & $\mathrm{RB}$ & $x$ & & $x$ \\
\hline $\begin{array}{l}\text { Upcher's Warbler } \\
\text { Hippolais languida }\end{array}$ & PM & $x$ & & \\
\hline $\begin{array}{l}\text { Icterine Warbler } \\
\text { Hippolais icterina }\end{array}$ & PM & & $x$ & \\
\hline $\begin{array}{l}\text { Arabian Warbler } \\
\text { Sylvia leucomelaena }\end{array}$ & RB & $?$ & $x$ & $x$ \\
\hline $\begin{array}{l}\text { Gambage Dusky Flycatcher } \\
\text { Muscicapa gambagae }\end{array}$ & $\mathrm{BM}$ & $x$ & $?$ & $x$ \\
\hline $\begin{array}{l}\text { Arabian Babbler } \\
\text { Turdoides squamiceps } \\
\text { yemenensis }\end{array}$ & $\mathrm{RB}$ & $x$ & & $x$ \\
\hline $\begin{array}{l}\text { Black-headed Bush Shrike } \\
\text { Tchagra senegala }\end{array}$ & RB & $x$ & & \\
\hline $\begin{array}{l}\text { Isabelline Shrike } \\
\text { Lanius isabellinus }\end{array}$ & PM/WV & $x$ & & \\
\hline $\begin{array}{l}\text { Red-backed Shrike } \\
\text { Lanius collurio }\end{array}$ & PM & $x$ & & \\
\hline $\begin{array}{l}\text { Great Grey Shrike } \\
\text { Lanius excubitor }\end{array}$ & RB & $x$ & & \\
\hline Masked Shrike Lanius nubicus & PM & $\times$ & & \\
\hline
\end{tabular}

aOpen ground around Raydah village, Wadis Jaw and Maraba and adjacent lower slopes.

'Raydah Reserve. Terraced farmland and juniper scrub and immediately east of Raydah Reserve. 
whether the Arabian juniper avifauna has evolved a high degree of specialization or dependence on junipers or whether this close association is accidental because there are few other types of mature and structurally similar woodland. With our current lack of knowledge this cannot be answered and much more research is needed on the seasonality of critical resources (food, nesting cover) present in juniper forest and other woodland or scrub habitats in the mountains and how this relates to bird density and activity.

Raydah Reserve is unique as it is the only forest protected area in the whole of the Arabian peninsula. Conservation of wildlife through the establishment of networks of protected areas is in its infancy in Arabian countries and at present most resources and effort are directed to high profile flagship species, usually desert-dwelling game such as Arabian Oryx Oryx leucoryx, gazelles and Houbara Bustard Chlamydotis undulata. Although Raydah has reserve status, little practical management is undertaken to ameliorate the various threats that such montane forest faces. Although several (2 or 3) NCWCD rangers are based at Raydah, their training, gained at other reserves, is primarily based on the prevention of poaching. The rangers' presence probably deters casual hunting of partridges, tree felling and possibly restricts encroachment of house building or farm expansion at the lower boundary of the Reserve. The principal threats to the forest are three-fold: grazing by domestic livestock, poor maintenance practices associated with keeping the dirt-road passable and natural die-back of the junipers. Goat herds are brought into the Reserve regularly from surrounding farms; grazing obviously removes herbage and ground flora and both this and trampling may retard tree regeneration. The goats cause rockfalls as they pass over steep terrain. A lesser number of free-ranging cattle owned by villagers adds to the grazing and trampling problems. Rockfalls onto the road are dealt with by bulldozing spoil over the downslope edge and a considerable tract of forest has been damaged in this way as the road winds through to $\mathrm{km}$ of the Reserve from the top to the village. The road cut reduces soil-water retention and increases gullying and erosion. Both stabilization of the road and prevention of grazing would certainly benefit the Reserve. Die-back of junipers and poor regeneration are widespread in south-west Saudi Arabia; a prolonged drought in the early 1960 s is thought to have been partially responsible, but the ability of the forest to recover through time, given sufficient rainfall, is not known.

Our purpose here has been to highlight the importance, as well as the plight, of the Reserve in international bird conservation circles and through such increased awareness we hope encouragement and assistance will be forthcoming to preserve the integrity of south-west Arabian juniper forests and Raydah in particular.

\section{Acknowledgements}

We are grateful to Abdullah Suhaibany, Hans Winkler, Walter Roggeman, David Houston, Simon Aspinall, Richard Newton, Mohammed Salama, Pascale Symens and Alistair Joliffe for help in the field. A special thank you goes to Peter Symens who has both assisted regularly and shown continual interest in the progress of the Raydah work. We are grateful to Hans Winkler and an 
anonymous referee for commenting on previous drafts. Logistical support and facilities were provided by NCWCD and the National Wildlife Research Center (Taif), and the tolerance of the farm owners, for regular intrusions on their land, is much appreciated.

\section{References}

Abo-Hassan, A. A. (1983) Type, distribution and area of forests in south-western region of Saudi Arabia. J. Coll. Agric., King Sand Univ. 5: 103-114.

Al-Hubaishi, A. and Müller-Hohenstein, K. (1984) An introduction to the vegetation of Yemen. Ecological basis, floristic composition, human influence. Eschborn: Deutsche Gesellschaft für Technische Zusammenarbeit.

Bates, G. L. (1937) Birds of 'Asir and parts of Hijaz and northern Yaman collected by H. St. J. B. Philby on his 1936 journey. Ibis 14: 786-830.

Bibby, C. J., Burgess, N. D. and Hill, D. A. (1992) Bird census techniques. London: Academic Press.

Brooks, D. J., Evans, M. I., Martins, R. P. and Porter, R. F. (1987) The status of birds in North Yemen and the records of OSME expedition in autumn 1985. Sandgrouse 9: 4-66.

Brown, I. J. A. (1993) Description of nest of Golden-winged Grosbeak. Orn. Soc. Middle East Bull. 31: 27-28.

Child, G. and Grainger, J. (1990) A system plan for protected areas for wildlife conservation and sustainable rural development in Saudi Arabia. Riyadh: The National Commission for Wildlife Conservation and Development.

Dawson, D. K. (1981) Sampling in rugged terrain. Stud. Avian Biol. 6: 311-315.

Evans, M. I. (compiler) (1994) Important bird areas in the Middle East. Cambridge, U.K.: BirdLife International (BirdLife Conserv. Ser. no. 2).

Gardner, A. S. and Fisher, M. (1994) How the forest lost its trees: Just So storytelling about Juniperus excelsa in Arabia. J. Arid Environ. 26: 299-301.

Hajar, A. S. (1991) Germination studies of Juniperus excelsa from south-western Saudi Arabia. Ind. Bot. Contact. 8: 41-44.

Hajar, A. S., Faragalla, A. A. and Al-Ghamdi, K. M. (1991) Impact of biological stress on Juniperus excelsa M. Bieb. in south-western Saudi Arabia: insect stress. J. Arid Environ. 21: 327-330.

ICBP (1992) Putting biodiversity on the map: priority areas for global conservation. Cambridge, U.K.: International Council for Bird Preservation.

Jennings, M. C. (1981) The birds of Saudi Arabia: a check-list. Cambridge, U.K.: privately published.

Jennings, M. C. (1986) The Olive Pigeon Columba arquatrix on Jebel Suda, Asir Province: a new bird species for Saudi Arabia and the Arabian Peninsula. J. Saudi Arabian Nat. Hist. Soc. 2: 35-36.

Jennings, M. C. (1995) An interim atlas of the breeding birds of Arabia. Riyadh: National Commission for Wildlife Conservation and Development.

Jennings, M. C., al Salama, M. I. and Felemban, H. M. (1988) Report on an ornithological survey of the Asir National Park, Saudi Arabia 29 June to 19 July 1987. Riyadh: National Commission for Wildlife Conservation and Development (ABBA survey no. 4).

Jones, P. S. (1991) Restoration of Juniperus excelsa Bieb. and Olea europaea L. subsp. africana Mill. (P. S. Green) woodlands in Eritrea. University of Stirling, Scotland: Unpublished Ph.D. thesis.

Karr, J. R. (1981) Surveying birds in the tropics. Stud. Avian Biol. 6: 548-553.

King, B. (1978) April bird observations in Saudi Arabia. J. Saudi Arabian Nat. Hist. Soc. 21: 3-24. 
König, P. (1986) Zonation of vegetation in the mountainous region of south-western Saudi Arabia ('Asir, Tihama). Pp. 137-166 in H. Kürschner, ed. Contributions to the vegetation of Southwest Asia. Weisbaden: Dr. Ludwig Reichert Verlag. (Beihefte zum Tübinger Atlas des Vorderen Orients, Reihe A, Nr. 24.)

Magurran, A. E. (1988) Ecological diversity and its measurement. London: Chapman and Hall.

Martins, R. P., Porter, R. F. and Stone, F. (1993) Preliminary report of the OSME survey of Southern Yemen and Socotra, Spring 1993. Sandy, U.K.: Ornithological Society of the Middle East.

McKinnon, M. (1990) Pp. 102-118 in Arabia - sand sea sky. London: BBC Publications.

Newton, S. F. (1994) Further notes on the nightjars of Arabia. Oman Bird News 15: 1-3.

Newton, S. F., Newton, A. V. and Winkler, H. (1994) The avifauna of Wadi Turabah: status, distribution and habitat associations. Fauna Saudi Arabia 14: 442-454.

Newton, S. F. and Newton, A. V. (in press) The effect of rainfall and habitat on abundance and diversity of birds in a fenced protected area in the central Saudi Arabian desert. J. Arid Environ.

Rahmani, A. R., Shobrak, M. Y. and Newton, S. F. (1994) Birds of the Tihamah coastal plains of Saudi Arabia. Orn.Soc. Middle East Bull. 32: 1-19.

Rands, M., Rands, G. and Porter, R. (1987) Birds in the Yemen Arab Republic: a report of the expedition of the Ornithological Society of the Middle East, October - December 1985. Sandy, U.K.: Ornithological Society of the Middle East.

Robinson, S. K., Fitzpatrick, J. W. and Terborgh, J. (1995) Distribution and habitat use of Neotropical migrant landbirds in the Amazon basin and Andes. Bird Conserv. Internatn. 5: 305-323.

Siraj, A. (1984) Climate of Saudi Arabia. Fauna Saudi Arabia 6: 32-52.

Smith, K. D. (1957) An annotated check list of the birds of Eritrea. Ibis 99: 1-26, 307-337.

Stagg, A. J. (1985) The birds of S. W. Saudi Arabia: an annotated check-list. Second edition. Riyadh: National Commission for Wildlife Conservation and Development.

Symens, P., Newton, S. F., Winkler, H. and Stagg, A. J. (1994) Mountain Nightjar Caprimulgus poliocephalus, in Arabia: identification, status and distribution. Sandgrouse 14: $81-92$.

Winkler, H., Newton, A. V. and Newton, S. F. (1996) On the ecology and beh-iour of the Arabian Woodpecker Picoides dorae. Zool. in the Middle East 12: 33-45.

STEPHEN F. NEWTON and ANNE V. NEWTON

National Commission for Wildlife Conservation and Development, P. O. Box 1086, Taif, Saudi Arabia.

Address for correspondence: Glenbeg, Kindlestown Hill, Delgany, Co. Wicklow, Ireland. 